\title{
Brown Adipose Tissue-A Therapeutic Target in Obesity?
}

\author{
Paul Trayhurn ${ }^{1,2 *}$ \\ ${ }^{1}$ Clore Laboratory, University of Buckingham, Buckingham, United Kingdom, ${ }^{2}$ Obesity Biology Unit, University of Liverpool, \\ Liverpool, United Kingdom
}

Keywords: brown adipocyte, beige adipocyte, obesity, thermogenesis, uncoupling protein-1

OPEN ACCESS

Edited by:

Rita De Matteis,

Università degli Studi di Urbino Carlo

Bo, Italy

Reviewed by:

Giovanni Solinas,

University of Gothenburg, Sweden Catalina Pico,

Universidad de les Illes Balears, Spain Marta Giralt,

University of Barcelona, Spain

*Correspondence: Paul Trayhurn p.trayhurn@liverpool.ac.uk

Specialty section:

This article was submitted to Integrative Physiology, a section of the journal Frontiers in Physiology

Received: 31 August 2018 Accepted: 07 November 2018 Published: 23 November 2018

Citation:

Trayhurn P (2018) Brown Adipose Tissue-A Therapeutic Target in Obesity? Front. Physiol. 9:1672. doi: 10.3389/fphys.2018.01672
Since brown adipose tissue (BAT) was first identified in the interscapular area of marmots by Gessner in 1551 (Smith and Horwitz, 1969), views on its functions have continued to evolve (Table 1). The initial proposition was that it was linked to hibernation, reflecting the fact that marmots are hibernating animals. This was followed sequentially by the view that BAT was part of the thymus (1670-1817), an endocrine gland active in the formation of blood (1817-63), a modified form of fat tissue providing a reservoir for food substances (1863-1902), and again as an endocrine gland (1902-61) (Afzelius, 1970). It was only in 1961 that the tissue was finally identified as an effecter of non-shivering thermogenesis (NST) and the "metabolic power" of brown adipocytes recognized (Smith and Horwitz, 1969).

There were three situations where BAT was understood to be highly active-during arousal from hibernation, in the response to cold-exposure of certain adult mammals, and in cold-stressed mammalian neonates (Smith and Horwitz, 1969). The quantitative importance of BAT to NST was initially unclear. However, in the late 1970's it was clarified in the case of cold-acclimated rodents by employing radioactively microspheres to map regional blood flow, these studies demonstrating that brown fat may account for up to two-thirds of heat from NST (Foster and Frydman, 1978, 1979). The mechanism for heat generation in brown adipocytes was also being explored, and the uncoupling of oxidative phosphorylation through proton leakage across the inner mitochondrial membrane was established as the pathway by which thermogenesis occurs (Nicholls and Locke, 1984). This proton conductance pathway was shown to be dependent on, and regulated by, a cold-inducible mitochondrial uncoupling protein-UCP1 (Ricquier and Kader, 1976; Nicholls and Locke, 1984; Ricquier, 2017).

Since these pivotal advances, perspectives on the physiology of BAT have continued to evolve. Here, recent views on the role of the tissue are summarized and the potential implications for the treatment of obesity considered.

\section{BAT AND NUTRITIONAL ENERGETICS}

A major new dimension emerged in the late 1970's with the establishment of a link between BAT and energy balance (Table 1). This resulted from two key observations, one of which was that rats exhibiting high rates of diet-induced thermogenesis on a cafeteria diet are characterized by an activation of BAT (Rothwell and Stock, 1979), including increased mitochondrial GDP binding indicative of an activation of the proton conductance pathway (Brooks et al., 1980). The other major observation was of decreased BAT activity, with a reduction in GDP binding, in obese (ob/ob) mice; this was proposed as a causative factor in the development of their obesity (Himms-Hagen and Desautels, 1978).

These pioneering observations resulted in a new paradigm in the etiology of obesity (Rothwell and Stock, 1981; Himms-Hagen, 1983, 1989; Trayhurn, 1989). A tissue and molecular basis for the reduced energy expenditure on facultative thermogenesis proposed as an important factor in the development of obesity had been identified. Abnormalities in BAT activity were subsequently 
TABLE 1 | Evolution of perspectives on the physiological functions and characteristics of brown adipose tissue.

\begin{tabular}{|c|c|}
\hline Year & Function \\
\hline 1551 & Description by Gessner-role in hibernation \\
\hline $1670-1817$ & Part of the thymus \\
\hline $1817-1863$ & An endocrine gland-and active in the formation of blood \\
\hline $1863-1902$ & $\begin{array}{l}\text { Modified form of fat tissue which serves as a reservoir for food } \\
\text { substances }\end{array}$ \\
\hline $1902-1961$ & An endocrine gland once more \\
\hline $1961-$ & Thermogenic organ-non-shivering thermogenesis \\
\hline $1974-7$ & $\begin{array}{l}\text { Elucidation of unique bioenergetic properties of brown fat } \\
\text { mitochondria (proton leak) }\end{array}$ \\
\hline $1976-8$ & Discovery of UCP1 \\
\hline 1978 & $\begin{array}{l}\text { Demonstration of quantitative importance to non-shivering } \\
\text { thermogenesis in cold-acclimated rodents }\end{array}$ \\
\hline 1978/9- & $\begin{array}{l}\text { Involved in energy balance (diet-induced thermogenesis) and } \\
\text { obesity }\end{array}$ \\
\hline 2009- & $\begin{array}{l}\text { Definitive identification of BAT in adult humans and its metabolic } \\
\text { plasticity }\end{array}$ \\
\hline 2010/12 & Discovery of "beige"/"brite" adipocytes \\
\hline $2011 / 12$ & $\begin{array}{l}\text { Role in glucose disposal and triglyceride clearance - metabolic } \\
\text { homeostasis }\end{array}$ \\
\hline
\end{tabular}

Based partly on Afzelius (1970).

reported in a range of animal obesities, including $d b / d b$ mice and Zucker $(f a / f a)$ rats, and in rodents with experimentally-induced obesity (Himms-Hagen, 1989; Trayhurn, 2017). The central role of BAT in nutritional energetics and body fat regulation was further evident from studies demonstrating changes in thermogenic activity in a range of physiological conditionsfrom fasting to lactation and photoperiod-induced seasonal changes in body weight (Trayhurn, 2017).

\section{BROWN ADIPOSE TISSUE IN MAN}

A widely debated question in the 1980's was the extent to which studies on laboratory rodents were relevant to energetics and obesity in humans. This was effectively two questionswhether reduced expenditure on thermogenesis underpins the development of human obesity, and whether BAT is present in adults and thus the potential locus of impaired thermogenesis. The first question has been the source of continuing debate, but what seems clear is that thermogenesis is not a major component of expenditure in adult humans (Wijers et al., 2007; van Marken Lichtenbelt and Schrauwen, 2011)-certainly compared with small rodents such as mice in the cold where it accounts for up to two-thirds of total expenditure (Trayhurn and James, 1978; Trayhurn, 1979).

In the early 1980's, BAT was considered, essentially on histological criteria, to be absent in humans after the first years of life. This parallels precocial species such as goats and sheep in which BAT, while abundant at birth, rapidly loses UCP1 and thermogenic capacity over the first weeks of postnatal life being replaced by white fat (Casteilla et al., 1987; Trayhurn et al., 1993).
Until 2009, the widely held view was that BAT (or thermogenic adipocytes) is absent from adult humans, despite anatomical studies identifying multi-locular adipocytes (Heaton, 1972), and more critically: (i) UCP1 being identified in adipose tissue depots of adults, including elderly subjects (Lean et al., 1986a), (ii) activation of BAT being demonstrated in phaeochromocytoma patients (Ricquier et al., 1982; Lean et al., 1986b), and (iii) UCP1 gene expression in adipose tissue of adults, particularly in phaeochromocytoma (Bouillaud et al., 1988).

The lack of recognition that adults do contain active BAT was a key element in the decline of interest in the tissue by the 1990's. However, over the past decade several major developments have led to a renewed focus on BAT. First, studies from the late 2000's utilizing FDG-PET (fluorodeoxyglucose positron emission tomography), commonly employed to track tumor metastasis, have mapped areas of high glucose uptake which also contain UCP1, thereby firmly identifying active BAT in adults (Cypess et al., 2009; Virtanen et al., 2009; Moonen et al., 2019). Through such studies, increased BAT activity has been observed in response to multiple stimuli, including cold exposure (as in rodents), and administration of insulin and the $\beta_{3}$-adrenoceptor agonist mirabregon (van Marken Lichtenbelt et al., 2009; Virtanen et al., 2009; Orava et al., 2011; Ouellet et al., 2012; Cypess Aaron et al., 2015). Importantly, the thermogenic activity of the tissue has been shown to decline with age and increasing BMI (Cypess et al., 2009; van Marken Lichtenbelt et al., 2009; Pfannenberg et al., 2010; Moonen et al., 2019).

\section{RECENT DEVELOPMENTS IN BAT PHYSIOLOGY}

An important development over the past decade, although not on BAT as such, is the discovery of a third form of adipocyte- "brite" or "beige" (Petrovic et al., 2010; Wu et al., 2012; Carobbio et al., 2019). These fat cells contain UCP1, providing the potential for thermogenesis, and have some of the other molecular signatures of brown adipocytes (Petrovic et al., 2010; Wu et al., 2012). Beige adipocytes are found primarily within WAT depots, and are recruited particularly during cold-exposure and following $\beta$ adrenergic stimulation resulting in the "browning" of white fat (Carobbio et al., 2019).

A further advance comes from evidence suggesting that BAT plays an important role in metabolic homeostasis, the tissue being a major site of glucose disposal, insulin action and triglyceride clearance (Bartelt et al., 2011; Stanford et al., 2013; Bartelt and Heeren, 2014). A high capacity for glucose uptake, which can be stimulated by insulin and cold, is evident from FDG-PET studies. Roles for BAT in glucose homeostasis and triglyceride clearance have led to the proposition that reduced activity in the tissue may underlie the metabolic syndrome (Nedergaard et al., 2011; Bartelt and Heeren, 2014; Moonen et al., 2019).

An additional dimension is the function of BAT as a secretory organ. Apart from the release of fatty acids, brown adipocytes synthesize and secrete multiple peptide/protein factors, these "brown adipokines" paralleling the adipokines of white adipocytes (Villarroya et al., 2013, 2017). While the 
adipokinome of white fat cells numbers several hundred entities (Trayhurn, 2013), it is unclear whether the secretome from brown adipocytes is as extensive. The brown adipokinome includes classical adipokines such as leptin and IL-6 (Villarroya et al., 2013, 2017), but brown adipocytes are unlikely to be an important source of these factors.

\section{BAT AS A THERAPEUTIC TARGET-IS IT REALISTIC?}

A major driver behind the renewed interest in BAT relates to its potential as a therapeutic target to treat obesity. This reflects the revival of a concept current in the 1980's, but it is now based on the firm acceptance that the tissue is present, thermogenically active and exhibits plasticity in adults. The ability to recruit beige adipocytes within WAT has further added to the focus on BAT (Petrovic et al., 2010; Wu et al., 2012; Jespersen Naja et al., 2013; Sacks et al., 2013), or more strictly on UCP1-dependent adipocyte thermogenesis, as a therapeutic route in obesity. But how realistic is this?

\section{The Case in Favor}

There are substantive points in favor of BAT as a target-which in principal can be through increasing the thermogenic activity/capacity of pre-existing brown adipocytes, by recruitment of new brown adipocytes, or a combination of the two. Additionally, there is the potential to recruit beige cells through "browning." BAT has the conceptual attraction of being a clearly defined target with a precise molecular end-point in the amount and activity of UCP1. It also centres on one specific element of energy balance-adaptive energy expenditure-so augmentation is a logical approach. Furthermore, as well as increasing expenditure it has the potential of improving metabolic homeostasis through its role in glucose utilization and lipid clearance (Nedergaard and Cannon, 2010; Bartelt and Heeren, 2014; Moonen et al., 2019).

\section{The Case Against}

There are, nevertheless, also substantive arguments against BAT as a realistic target. A key requirement is that the stimulation of energy expenditure through BAT does not lead to a compensatory increase in energy intake, which would be counter-productive. It is uncertain whether compensation would occur under normal circumstances; however, increased intake is very evident in rodents in the cold, with for example mice consuming three times more food at $4{ }^{\circ} \mathrm{C}$ than at thermoneutrality (Trayhurn, 1981), suggesting that increased BAT activity is linked to higher intake.

A critical issue is the quantitative importance of BAT thermogenesis to energy expenditure in adults. Clearly, if the contribution is minimal then it is a less obvious target for modulating energy balance-though a small, but sustained, imbalance between expenditure and intake would be effective. Estimates of the importance of BAT in energy expenditure range from 1 to $5 \%$ of RMR, but these are in effect basal values and it is argued that with stimulation the value will be higher at up to $16 \%$ of RMR (van der Lans et al., 2013; Moonen et al., 2019)-this can be viewed as part of the "case in favor."

A number of approaches to increasing the thermogenic activity and capacity of BAT have been proposed. The initial route was to design selective $\beta_{3}$-agonists, reflecting the centrality of the $\beta_{3}$-adrenoceptor in the regulation of thermogenesis, and several were developed (Arch, 2002). However, although the first generation compounds were effective in stimulating expenditure and reversing obesity in rodents, their efficacy and potency in humans is poor due to a combination of factors including sequence differences between the human and rodent $\beta_{3}$-adrenoceptor (Arch, 2002). Nevertheless, selective $\beta_{3}$ agonists continue to be of interest with mirabegron having recently been shown to stimulate RMR and glucose uptake by BAT (Cypess Aaron et al., 2015). Alternative strategies have been proposed and these include central stimulation of the sympathetic innervation to BAT, brown fat transplantation and stem cell therapy (Gunawardana and Piston, 2012; Nishio et al., 2012; Guénantin et al., 2017; Carobbio et al., 2019). While potentially feasible, it is difficult to regard transplantation and stem cell therapy as practical approaches to obesity treatment.

Recruitment of beige cells would augment the number of thermogenic adipocytes, and multiple factors can facilitate this process (Bartelt and Heeren, 2014; Nedergaard and Cannon, 2014; Carobbio et al., 2019). There are, however, potential constraints on whether beige adipocytes may provide significant amounts of heat-apart from any intracellular limitation. To make a significant contribution to NST, close proximity to an extensive vascular network would be expected, both to rapidly dissipate the heat generated and to provide oxygen and other nutrients to fuel high rates of thermogenesis. Furthermore, thermogenesis requires noradrenergic stimulation, and the recruitment of beige adipocytes needs to be accompanied by local growth of the sympathetic innervation. A report that alternatively activated macrophages stimulate thermogenesis in BAT through the secretion of catecholamines (Nguyen et al., 2011) has not been supported subsequently (Fischer et al., 2017); however, the hormone meterorin-like promotes browning through M2 macrophage activation (Rao et al., 2014).

The final reservation to treating obesity through the stimulation of BAT thermogenesis lies in the potential cardiovascular risk. While this may be small, and needs to be balanced against the risks associated with obesity itself, regulatory agencies are likely to be ultra-cautious given the readiness with which previous anti-obesity drugs have been withdrawn following evidence of adverse effects.

\section{CONCLUDING COMMENTS}

Our understanding of the functions of BAT has continued to evolve and it is evident that the tissue has multiple actions beyond a core thermoregulatory role. Recognition of its involvement in nutritional energetics and the etiology of obesity in the late 1970's transformed perspectives on the tissue. Over the past decade there has been a renaissance of interest in BAT, following clear 
evidence of its presence and metabolic plasticity in adult humans. There is currently considerable focus on BAT as a therapeutic target in the treatment of obesity and its associated metabolic disorders, aided by the identification of beige adipocytes and the phenomenon of browning of WAT. However, it is suggested that in totality there are formidable barriers to this approach and that the stimulation and recruitment of thermogenic adipocytes

\section{REFERENCES}

Afzelius, B. A. (1970). "Brown adipose tissue: its gross anatomy, histology, and cytology," in Brown Adipose Tissue, ed. O. Lindberg (New York, NY: American Elsevier), 1-31.

Arch, J. R. (2002). $\beta_{3}$-Adrenoceptor agonists: potential, pitfalls and progress. Eur. J. Pharmacol. 440, 99-107. doi: 10.1016/S0014-2999(02)01421-8

Bartelt, A., Bruns, O. T., Reimer, R., Hohenberg, H., Ittrich, H., Peldschus, K., et al. (2011). Brown adipose tissue activity controls triglyceride clearance. Nat. Med. 17, 200-205. doi: 10.1038/nm.2297

Bartelt, A., and Heeren, J. (2014). Adipose tissue browning and metabolic health. Nat. Rev. Endocrinol. 10, 24-36. doi: 10.1038/nrendo.2013.204

Bouillaud, F., Villarroya, F., Hentz, E., Raimbault, S., Cassard, A. M., and Ricquier, D. (1988). Detection of brown adipose tissue uncoupling protein mRNA in adult humans by a genomic probe. Clin. Sci. 75, 21-27. doi: 10.1042/cs07 50021

Brooks, S. L., Rothwell, N. J., Stock, M. J., Goodbody, A. E., and Trayhurn, P. (1980). Increased proton conductance pathway in brown adipose tissue mitochondria of rats exhibiting diet-induced thermogenesis. Nature 286, 274-276. doi: 10.1038/286274a0

Carobbio, S., Guénantin, A.-C., Samuelson, I., Bahri, M., and Vidal-Puig, A. (2019). Brown and beige fat: from molecules to physiology and pathophysiology. Biochim. Biophys. Acta Mol. Cell Biol. Lipids. 1864, 37-50. doi: 10.1016/j.bbalip.2018.05.013

Casteilla, L., Forest, C., Robelin, J., Ricquier, D., Lombet, A., and Ailhaud, G. (1987). Characterization of mitochondrial-uncoupling protein in bovine fetus and newborn calf. Am. J. Physiol. Endocrinol. Metab. 252, E627-E636. doi: 10.1152/ajpendo.1987.252.5.E627

Cypess Aaron, M., Weiner Lauren, S., Roberts-Toler, C., Elía Elisa, F., Kessler Skyler, H., Kahn Peter, A., et al. (2015). Activation of human brown adipose tissue by a $\beta 3$-adrenergic receptor agonist. Cell Metab. 21, 33-38. doi: 10.1016/j.cmet.2014.12.009

Cypess, A. M., Lehman, S., Williams, G., Tal, I., Rodman, D., Goldfine, A. B., et al. (2009). Identification and importance of brown adipose tissue in adult humans. N. Engl. J. Med. 360, 1509-1517. doi: 10.1056/NEJMoa0810780

Fischer, K., Ruiz, H. H., Jhun, K., Finan, B., Oberlin, D. J., van der Heide, V., et al. (2017). Alternatively activated macrophages do not synthesize catecholamines or contribute to adipose tissue adaptive thermogenesis. Nat. Med. 23, 623-630. doi: $10.1038 / \mathrm{nm} .4316$

Foster, D. O., and Frydman, M. L. (1978). Nonshivering thermogenesis in the rat. II. Measurements of blood flow with microspheres point to brown adipose tissue as the dominant site of the calorigenesis induced by noradrenaline. Can J. Physiol. Pharmacol. 56, 110-122. doi: 10.1139/y78-015

Foster, D. O., and Frydman, M. L. (1979). Tissue distribution of cold-induced thermogenesis in conscious warm- or cold-acclimated rats re-evaluated from changes in tissue blood flow: the dominant role of brown adipose tissue in the replacement of shivering by non-shivering thermogenesis. Can J. Physiol. Pharmacol. 57 257-270. doi: 10.1139/y79-039

Guénantin, A.-C., Briand, N., Capel, E., Dumont, F., Morichon, R., Provost, C., et al. (2017). Functional human beige adipocytes from induced pluripotent stem cells. Diabetes 66, 1470-1478. doi: 10.2337/db16-1107

Gunawardana, S. C., and Piston, D. W. (2012). Reversal of type 1 diabetes in mice by brown adipose tissue transplant. Diabetes 61, 674-682. doi: $10.2337 / \mathrm{db} 11-0510$

Heaton, J. (1972). The distribution of brown adipose tissue in the human. J. Anatll. $2,35-39$. is unlikely to provide a realistic anti-obesity/anti-metabolic syndrome strategy in the near-future.

\section{AUTHOR CONTRIBUTIONS}

The author confirms being the sole contributor of this work and has approved it for publication.

Himms-Hagen, J. (1983). Brown adipose tissue thermogenesis; energy balance; and obesity. Can J. Biochem. Cell Biol. 62, 610-617.

Himms-Hagen, J. (1989). Brown adipose tissue thermogenesis and obesity. Prog. Lipid Res. 28, 67-115.

Himms-Hagen, J., and Desautels, M. (1978). A mitochondrial defect in brown adipose tissue of the obese $(o b / o b)$ mouse: reduced binding of purine nucleotides and a failure to respond to cold by an increase in binding. Biochem. Biophys. Res. Commun. 83, 628-634. doi: 10.1016/0006-291X(78)91036-7

Jespersen Naja, Z., Larsen Therese, J., Peijs, L., Daugaard, S., Homøe, P., Loft, A., et al. (2013). A Classical brown adipose tissue mRNA signature partly overlaps with brite in the supraclavicular region of adult humans. Cell Metab. 17, 798-805. doi: 10.1016/j.cmet.2013.04.011

Lean, M. E., James, W. P., Jennings, G., and Trayhurn, P. (1986a). Brown adipose tissue uncoupling protein content in human infants, children and adults. Clin. Sci. 7l, 29l-297. doi: 10.1042/cs0710291

Lean, M. E. J., James, W. P. T., Jennings, G., and Trayhurn, P. (1986b). Brown adipose tissue in patients with phaeochromocytoma. Int. J. Obesity 10, 219-27.

Moonen, M. P. B., Nascimento, E. B. M., and van Marken Lichtenbelt, W. D. (2019). Human brown adipose tissue: underestimated target in metabolic disease? Biochim. Biophys. Acta Mol. Cell Biol. Lipids. 1864, 104-112. doi: 10.1016/j.bbalip.2018.05.012

Nedergaard, J., Bengtsson, T., and Cannon, B. (2011). New powers of brown fat: fighting the metabolic syndrome. Cell Metab. 13, 238-240. doi: 10.1016/j.cmet.2011.02.009

Nedergaard, J., and Cannon, B. (2010). The changed metabolic world with human brown adipose tissue: therapeutic visions. Cell Metab. 11, 268-272. doi: 10.1016/j.cmet.2010.03.007

Nedergaard, J., and Cannon, B. (2014). The browning of white adipose tissue: some burning issues. Cell Metab. 20, 396-407. doi: 10.1016/j.cmet.2014. 07.005

Nguyen, K. D., Qiu, Y., Cui, X., Goh, Y. P., Mwangi, J., David, T., et al. (2011). Alternatively activated macrophages produce catecholamines to sustain adaptive thermogenesis. Nature 480, 104-108. doi: 10.1038/nature10653

Nicholls, D. G., and Locke, R. M. (1984). Thermogenic mechanisms in brown fat. Physiol. Rev.64, 1-64. doi: 10.1152/physrev.1984.64.1.1

Nishio, M., Yoneshiro, T., Nakahara, M., Suzuki, S., Saeki, K., Hasegawa, M., et al. (2012). Production of functional classical brown adipocytes from human pluripotent stem cells using specific hemopoietin cocktail without gene transfer. Cell Metab. 16, 394-406. doi: 10.1016/j.cmet.2012.10.011

Orava, J., Nuutila, P., Lidell, M. E., Oikonen, V., Noponen, T., Viljanen, T., et al. (2011). Different metabolic responses of human brown adipose tissue to activation by cold and insulin. Cell Metab. 14, 272-279. doi: 10.1016/j.cmet.2011.06.012

Ouellet, V., Labbé, S. M., Blondin, D. P., Phoenix, S., Guérin, B., Haman, F., et al. (2012). Brown adipose tissue oxidative metabolism contributes to energy expenditure during acute cold exposure in humans. J. Clin. Invest. 122, 545-552. doi: 10.1172/JCI60433

Petrovic, N., Walden, T. B., Shabalina, I. G., Timmons, J. A., Cannon, B., and Nedergaard, J. (2010). Chronic peroxisome proliferator-activated receptor $\gamma$ (PPAR $\gamma)$ Activation of epididymally derived white adipocyte cultures reveals a population of thermogenically competent, UCP1-containing adipocytes molecularly distinct from classic brown adipocytes. J. Biol. Chem. 285, 7153-7164. doi: 10.1074/jbc.M109.053942

Pfannenberg, C., Werner, M. K., Ripkens, S., Stef, I., Deckert, A., Schmadl, M., et al. (2010). Impact of age on the relationships of brown adipose tissue with sex and adiposity in humans. Diabetes 59, 1789-1793. doi: 10.2337/db10-0004 
Rao, R. R., Long, J. Z., White, J. P., Svensson, K. J., Lou, J., Lokurkar, I., et al. (2014). Meteorin-like is a hormone that regulates immune-adipose interactions to increase beige fat thermogenesis. Cell 157, 1279-1291. doi: 10.1016/j.cell.2014.03.065

Ricquier, D. (2017). UCP1, the mitochondrial uncoupling protein of brown adipocyte: a personal contribution and a historical perspective. Biochimie 134, 3-8. doi: 10.1016/j.biochi.2016.10.018

Ricquier, D., and Kader, J. C. (1976). Mitochondrial protein alterations in active brown fat: a sodium dodecyl sulfate-polyacrylamide gel electrophoretic study. Biochem. Biophys. Res. Commun. 73, 577-583. doi: 10.1016/0006-291X(76)90849-4

Ricquier, D., Nechad, M., and Mory, G. (1982). Ultrastructural and biochemical characterization of human brown adipose tissue in pheochromocytoma. J. Clin. Endocrinol. Metab. 54, 803-807.

Rothwell, N. J., and Stock, M. J. (1979). A role for brown adipose tissue in diet-induced thermogenesis. Nature 281, 31-35. doi: 10.1038/281031a0

Rothwell, N. J., and Stock, M. J. (1981). Regulation of energy balance. Ann. Rev. Nutr. 1, 235-256. doi: 10.1146/annurev.nu.01.070181.001315

Sacks, H. S., Fain, J. N., Bahouth, S. W., Ojha, S., Frontini, A., Budge, H., et al. (2013). Adult epicardial fat exhibits beige features. J. Clin. Endocrinol. Metab. 98, E1448-E1455. doi: 10.1210/jc.2013-1265

Smith, R. E., and Horwitz, B. A. (1969). Brown fat and thermogenesis. Physiol. Rev.49, 330-425. doi: 10.1152/physrev.1969.49.2.330

Stanford, K. I., Middelbeek, R. J., Townsend, K. L., An, D., Nygaard, E. B., Hitchcox, K. M., et al. (2013). Brown adipose tissue regulates glucose homeostasis and insulin sensitivity. J. Clin. Invest. 123, 215-223. doi: $10.1172 /$ JCI62308

Trayhurn, P. (1979). Thermoregulation in the diabetic-obese $(d b / d b)$ mouse. The role of non-shivering thermogenesis in energy balance. Pflügers Arch. 380, 227-232.

Trayhurn, P. (1981). Fatty acid synthesis in mouse brown adipose tissue: the influence of environmental temperature on the proportion of whole-body synthesis in brown adipose tissue and the liver. Biochim. Biophys. Acta. 664, 549-560. doi: 10.1016/0005-2760(81)90132-6

Trayhurn, P. (1989). "Brown adipose tissue and energy balance," in Brown Adipose Tissue, ed P. Trayhurn and D. G. Nicholls (London: Edward Arnold), 299-388.

Trayhurn, P. (2013). Hypoxia and adipose tissue function and dysfunction in obesity. Physiol. Rev. 93, 1-21. doi: 10.1152/physrev.00017.2012

Trayhurn, P. (2017). Origins and early development of the concept that brown adipose tissue thermogenesis is linked to energy balance and obesity. Biochimie 134, 62-70. doi: 10.1016/j.biochi.2016.09.007

Trayhurn, P., and James, W. P. (1978). Thermoregulation and non-shivering thermogenesis in the genetically obese $(o b / o b)$ mouse. Pflügers Arch. 373, 189-193.
Trayhurn, P., Thomas, M. E., and Keith, J. S. (1993). Postnatal development of uncoupling protein, uncoupling protein mRNA, and GLUT4 in adipose tissues of goats. Am. J. Physiol. Reg. Integr. Comp. Physiol. 265, R676-R682. doi: 10.1152/ajpregu.1993.265.3.R676

van der Lans, A. A., Hoeks, J., Brans, B., Vijgen, G. H., Visser, M. G., Vosselman, M. J., et al. (2013). Cold acclimation recruits human brown fat and increases nonshivering thermogenesis. J. Clin Investig. 123, 3395-3403. doi: 10.1172/JCI68993

van Marken Lichtenbelt, W. D., and Schrauwen, P. (2011). Implications of nonshivering thermogenesis for energy balance regulation in humans. Am. J. Physiol. Reg. Integr. Comp. Physiol. 301, R285-R296. doi: 10.1152/ajpregu.00652.2010

van Marken Lichtenbelt, W. D., Vanhommerig, J. W., Smulders, N. M., Drossaerts, J. M., Kemerink, G. J., Bouvy, N. D., et al. (2009). Cold-activated brown adipose tissue in healthy men. N. Engl. J. Med. 360, 1500-1508. doi: 10.1056/NEJMoa0808718

Villarroya, F., Gavaldà-Navarro, A., Peyrou, M., Villarroya, J., and Giralt, M. (2017). The lives and times of brown adipokines. Trends Endocrinol. Metab. 28, 855-867. doi: 10.1016/j.tem.2017.10.005

Villarroya, J., Cereijo, R., and Villarroya, F. (2013). An endocrine role for brown adipose tissue? Am. J. Physiol. Endocrinol. Metab. 305, E567-E572. doi: 10.1152/ajpendo.00250.2013

Virtanen, K. A., Lidell, M. E., Orava, J., Heglind, M., Westergren, R., Niemi, T., et al. (2009). Functional brown adipose tissue in healthy adults. N. Engl. J. Med. 360, 1518-1525. doi: 10.1056/NEJMoa0808949

Wijers, S. L., Saris, W. H., and van Marken Lichtenbelt, W. D. (2007) Individual thermogenic responses to mild cold and overfeeding are closely related. J. Clin. Endocrinol. Metab. 92, 4299-4305. doi: 10.1210/jc.20 07-1065

Wu, J., Boström, P., Sparks Lauren, M., Ye, L., Choi Jang, H., Giang, A.H., et al. (2012). Beige Adipocytes are a distinct type of thermogenic fat cell in mouse and human. Cell 150, 366-376. doi: 10.1016/j.cell.2012. 05.016

Conflict of Interest Statement: The author declares that the research was conducted in the absence of any commercial or financial relationships that could be construed as a potential conflict of interest.

Copyright (c) 2018 Trayhurn. This is an open-access article distributed under the terms of the Creative Commons Attribution License (CC BY). The use, distribution or reproduction in other forums is permitted, provided the original author $(s)$ and the copyright owner(s) are credited and that the original publication in this journal is cited, in accordance with accepted academic practice. No use, distribution or reproduction is permitted which does not comply with these terms. 